\title{
AMPA-Kainate Subtypes of Glutamate Receptor in Rat Cerebral Microglia
}

\author{
Mami Noda, ${ }^{1}$ Hiroshi Nakanishi, ${ }^{2}$ Junichi Nabekura, ${ }^{1}$ and Norio Akaike ${ }^{1}$ \\ 1 Laboratory of Cellular and System Physiology, Graduate School of Medical Science, and 2Department of Pharmacology, \\ Faculty of Dentistry, Kyushu University, Fukuoka 812-8582, Japan
}

Microglial cells were isolated from rat cerebral cortex, and kainate (KA)-induced inward current was measured at a holding potential of -40 or $-60 \mathrm{mV}$. 6-Cyano-7-nitroquinoxaline-2, 3-dione-sensitive KA-induced currents increased with increasing KA concentration. The half-activation concentration and Hill coefficient were $3.3 \times 10^{-4} \mathrm{M}$ and 1.4 , respectively. Although glutamate (Glu) and AMPA-induced currents were much smaller than that induced by KA, all KA-, Glu-, and AMPA-induced currents were greatly and consistently enhanced in the presence of cyclothiazide (CTZ). On the other hand, KA-induced currents were much less sensitive to potentiation by concanavain $A$, suggesting that the $K A$-induced response in rat microglia is predominantly mediated by AMPA-preferring receptors (subunits GluR1-GluR4). The current-voltage relationships of KA- and AMPA-CTZ-induced currents were almost linear or slightly outward rectifying. The reversal potential of

There is increasing evidence that functional glutamate receptors (GluR) are not restricted to neurons but are also expressed in glial cells. Among glial cells, macroglial cell types, astrocytes, and oligodendrocytes express various types of Glu receptors (for review, see Steinhäuser and Gallo, 1996). The possible functional roles of Glu receptors have been analyzed (Bowman and Kimelberg, 1984; Sontheimer et al., 1988; Gallo et al., 1989; Usowicz et al., 1989; Cornell-Bell et al., 1990; Parpura et al., 1994; Queiroz et al., 1997; Bezzi et al., 1998) and indicated the active glial participation in information processing and plasticity, as well as in pathological states. Glial precursor cells, oligodendrocyte-type 2 astrocyte (O-2A) cells, also express various Glu receptors (Patneau et al., 1994; Wang et al., 1996). The activation of Glu receptors modulates the proliferation and differentiation of $\mathrm{O}-2 \mathrm{~A}$ cells, suggesting that the excitatory transmitter might be one of the environmental signals that regulate glial cell development (Steinhäuser and Gallo, 1996; Matute et al., 1997). Moreover, another neuron-glia interaction between Purkinje cells and Berg-

\footnotetext{
Received April 30, 1999; revised Oct. 13, 1999; accepted Oct. 18, 1999.

This work was supported by Grants-in-Aid for Scientific Research Grants 11671845 (H.N.), 11170240 (J.N.), and 10470009 (N.A.) from the Ministry of Education, Science, and Culture, Japan, and the Hayashi Memorial Foundation for Female Natural Scientists (M.N.). We thank Dr. N. Takai (Kyushu University) for assistance with the preparation of the primary cultured microglia, Dr. T. Fukuda (Kyushu University) for helping us with the confocal laser scanning microscope, and Prof. D. A. Brown (University College, London, UK) and Dr. M. Brodwick (University of Texas Medical Branch, Galveston, TX) for reading this manuscript.

Correspondence should be addressed to Dr. Norio Akaike, Laboratory of Cellular and System Physiology, Graduate School of Medical Science, Kyushu University, Fukuoka 812-8582, Japan. E-mail: akaike@mailserver.med.kyushu-u.ac.jp.

Dr. Noda's present address; Laboratory of Pathophysiology, Graduate School of Pharmaceutical Science, Kyushu University, Fukuoka 812-8582, Japan

Copyright (C) 1999 Society for Neuroscience $\quad 0270-6474 / 99 / 200251-08 \$ 15.00 / 0$
}

KA-induced current shifted to negative potentials (from +4 to $-40 \mathrm{mV}$ ) on switching from high $\mathrm{Na}^{+}$to high $\mathrm{Ca}^{2+}$ external solution, indicating the low $\mathrm{Ca}^{2+}$ permeability through the AMPA-KA receptor channel complexes. AMPA-KA receptor expression was studied with immunohistochemistry and reverse transcription-PCR, from which GluR2, GluR3, GluR4, and GluR5 were identified. Lower levels of mRNAs for GluR7 and KA-1-KA-2 were also indicated. Finally, activation of these receptors with KA or Glu significantly enhanced the production of tumor necrosis factor- $\alpha$. These results suggest that primary cultured rat microglia possesses functional Glu receptor, which may mediate neuron to microglia communication in the physiological and pathological states.

Key words: microglia; whole-cell patch clamp; kainate; glutamate; AMPA; cyclothiazide; reverse transcription-PCR; tumor necrosis factor- $\alpha$ man glial cells via Glu receptors has been proposed in the cerebellum (Müller et al., 1992).

The question then arises whether microglia have Glu receptors. Microglial cells are rapidly activated even in response to minor pathological changes so that they may be viewed as the cellular sensory element of brain pathology (Kreutzberg, 1996) and may contribute to neurodegenerative diseases and to the dementia of AIDS (Streit and Kincaid-Colton, 1995). The most prominent feature of activated microglia is the generation of both neurotrophic (Mallat et al., 1989; Shimojo et al., 1991; Araujo and Cotman, 1992; Nakajima et al., 1992a,b) and neurotoxic molecules (Meda et al., 1995; El Khoury et al., 1996; Wyss-Coray et al., 1997; Noda et al., 1999). Furthermore, microglial cells have metabotropic and ionotropic receptors, such as endothelin and ATP receptors, that link to intracellular calcium signaling (Verkhratsky and Kettenmann, 1996; Chessell et al., 1997; Möller et al., 1997; Inoue et al., 1998). On the basis of these characteristics of microglia, Glu appears to be also a good candidate to mediate neuron-to-microglia communication in both physiological and pathological states. So far, however, there is no evidence showing ionotropic Glu receptors in microglia. In the present study, we therefore conducted electrophysiological study using a "Y tube" technique, which enables a rapid application of drugs (e.g., within $20 \mathrm{msec}$ ) (Min et al., 1996), in combination with benzothiazide cyclothiazide (CTZ) and concanavalin A, which block desensitization of AMPA-preferring receptors and kainate (KA)-preferring receptors, respectively. In this paper, we provide evidence for the existence of AMPA-KA receptors in primary cultured rat microglia by electrophysiolgical, immunohistochemical, and reverse transcription-PCR (RT-PCR) studies. We also 
show that activation of these receptors is involved in the production of tumor necrosis factor- $\alpha$ (TNF- $\alpha)$ by microglia.

\section{MATERIALS AND METHODS}

Materials. Papain and DNase were purchased from Worthington Biochemical (Freehold, NJ). DMEM was obtained from Life Technologies (Grand Island, NY). Fetal calf serum (FCS) was from HyClone (Logan, UT). 1,1'-Dioctadecyl-3,3,3',3'-tetramethyl-indo-carbocyanine bound to acetylated low-density lipoprotein (DiI-ac-LDL) and streptavidin-Alexia 488 were obtained from Molecular Probes (Eugene, OR). Antiglutamate receptor 2 and 3 antibody, recognizing both GluR2 and GluR3, was from Chemicon (Temecula, CA). Streptavidin-Cy3 was from Amersham (Buckinghamshire, UK). KA, Glu, NMDA, AMPA, quisqualate (QA), cremophore EL, Griffonia simplicifonia $\mathrm{B}_{4}$-isolectin (GSA-I-B ( $_{4}$, and concanavalin A were purchased from Sigma (St. Louis, MO). CNQX was from Tocris Cookson (Bristol, UK). CTZ was obtained from Research Biochemicals (Natick, MA).

Cell culture. Microglial cells were isolated from the mixed cultures of cerebrocortical cells from postnatal day 3 Wistar rats (Seac Yoshitomi, Fukuoka, Japan), as described previously (Sastradipura et al., 1998; Noda et al., 1999). In brief, the cerebral cortex was minced and treated with papain $(90 \mathrm{U})$ and DNase $(2000 \mathrm{U})$ at $37^{\circ} \mathrm{C}$ for $20 \mathrm{~min}$. The dissociated cells were seeded into $300 \mathrm{~cm}^{2}$ plastic flasks at a density of $10^{7} / 300 \mathrm{~cm}^{2}$ in DMEM with $0.37 \% \mathrm{NaHCO}_{3}, 50 \mathrm{U} / \mathrm{ml}$ penicillin, $100 \mathrm{mg} / \mathrm{ml}$ streptomycin, and $10 \% \mathrm{FCS}$, and maintained at $37^{\circ} \mathrm{C}$ in $10 \% \mathrm{CO}_{2}-90 \%$ air with a change of medium twice per week. After 10-14 d, floating cells and weakly attached cells on the mixed primary culture cell layer were obtained by gently shaking for 3-5 min. The resulting cell suspension was seeded onto glass coverslips and allowed to adhere for $30 \mathrm{~min}$ at $37^{\circ} \mathrm{C}$. Then, microglia were isolated as strongly adhering cells after unattached cells were removed. The purity of microglia was ranged from 92 to $95 \%$ as determined by immunostaining with OX42 directed against CR3 receptors or OX6 directed against major histocompatibility complex class II molecules. Microglial cells were maintained in the medium mentioned above at $37^{\circ} \mathrm{C}$ in $10 \% \quad \mathrm{CO}_{2}-90 \%$ air until the electrophysiological experiments.

Cell identification before electrophysiological measurements. Microglial cells were identified by the fluorescent probe DiI-ac-LDL. Cells were incubated with DiI-ac-LDL in a concentration of $10 \mu \mathrm{g} / \mathrm{ml}$ for $12 \mathrm{hr}$ at $37^{\circ} \mathrm{C}$ and visualized on an inverted fluorescent microscope before electrophysiological measurements. Most cells were round- or rod-shaped cell bodies with the diameter of $<10 \mu \mathrm{m}$, and some of them had few thick processes.

Electrophysiological measurements. Whole-cell recordings were made as reported previously (Noda et al., 1998, 1999). Microglial cells were whole-cell clamped using a patch pipette containing (in $\mathrm{mM}$ ): $\mathrm{NaCl}$ or CsCl 100, $\mathrm{Na}_{2} \mathrm{ATP} 3$, HEPES 5, $\mathrm{CaCl}_{2} 1, \mathrm{MgCl}_{2}$ 4, EGTA 5, and $N$-methyl-D-glucamine (NMDG) 10 . The $\mathrm{pH}$ of the solution was adjusted to 7.3 with $1 \mathrm{~N} \mathrm{HCl}$. The pipette resistance was $6-9 \mathrm{M} \Omega$. The external solution contained (in $\mathrm{mM}$ ): $\mathrm{KCl} 2.5, \mathrm{NaCl} 110, \mathrm{CaCl}_{2} 3, \mathrm{BaCl}_{2} 6$, glucose 15, and HEPES 5, and the pH was adjusted to 7.4 with NMDG. The high $\mathrm{Ca}^{2+}$ solution contained (in $\mathrm{mM}$ ): $\mathrm{CaCl}_{2} 80$, glucose 15 , and HEPES 5, and the $\mathrm{pH}$ was adjusted to 7.4 with NMDG. The external KA or drugs were applied rapidly using the $\mathrm{Y}$ tube technique (Min et al., 1996), which allows the complete exchange of the external solution surrounding a cell within $20 \mathrm{msec}$. The temperature monitored in the recording dishes was $33-34^{\circ} \mathrm{C}$.

The electrophysiological data are presented as means \pm SEM in the text, and the SEM is indicated by a vertical bar in the figures.

Fluorescent immunohistochemistry. Primary cultured microglia plated on the chamber slides were fixed with $4 \%$ paraformaldehyde for $30 \mathrm{~min}$ at room temperature, followed by a wash with PBS. For immunohistochemical staining of Glu receptors, the cells were treated as follows: with $3 \%$ normal goat serum for $4 \mathrm{hr}$ at room temperature; with anti-glutamate receptor 2 and 3 antibody recognizing both GluR2 and GluR3 over night at $4^{\circ} \mathrm{C}$; and stained with streptavidin-Alexia 488 for $2 \mathrm{hr}$ at room temperature. Controls were incubated with nonimmune rabbit IgG instead of anti-GluR2 and 3 antibody. For the identification of microglia, the same cells were treated with GSA-I- $B_{4}$ overnight at $4^{\circ} \mathrm{C}$ and stained with streptavidin-Cy3 for $2 \mathrm{hr}$ at room temperature. Every treatment was followed by washing with PBS. Then, the cells were mounted in the anti-fading medium Vectashield (Vector Laboratories, Burlingame, CA) and were examined with a confocal laser scanning microscope MRC1000 (Bio-Rad, Herz, UK) equipped with a krypton-argon ion laser and mounted on a light microscope (Nikon Optiphoto, Tokyo, Japan).
RT-PCR analysis. General methods were similar to those described previously (Stefani et al., 1998). Cells were cultured in $100 \mathrm{~mm}$ dishes and harvested, and cellular mRNA was extracted using TRIZOL (Life Technologies), according to the protocol provided by the manufacturer. Single-strand cDNA was synthesized from the cellular mRNA by adding SuperScript II RT $(1 \mu \mathrm{l} ; 200 \mathrm{U} / \mu \mathrm{l})$, buffer $[10 \mu \mathrm{l} ; 5 \times$ First Strand Buffer (in $\mathrm{mM}$ ): contains 250 Tris- $\mathrm{HCl}, 375 \mathrm{KCl}$, and $15 \mathrm{MgCl}_{2}$ ], DTT ( $5 \mu \mathrm{l} ; 0.1$ M), and mixed dNTPs $(18 \mu \mathrm{l} ; 2.5 \mathrm{~mm})$. The mixture $(45 \mu \mathrm{l})$ was incubated for $50 \mathrm{~min}$ at $42^{\circ} \mathrm{C}$. The reaction was terminated by heating the mixture to $70^{\circ} \mathrm{C}$ for $2 \mathrm{~min}$ and then icing. The RNA strand in the RNA-DNA hybrid was removed by adding $5 \mu \mathrm{l}$ of RNase $\mathrm{H}(2 \mathrm{U} / \mu \mathrm{l})$ and incubating for $1 \mathrm{hr}$ at $37^{\circ} \mathrm{C}$. All reagents were obtained from Life Technologies. The DNA from the RT of RNA in microglia was subjected to PCR to detect the expression of GluR mRNAs.

Amplification was performed on a thermal cycler (PC800; Astec, Fukuoka, Japan) using DNA polymerase, LA Taq (TaKaRa, Tokyo, Japan) under the following cycle conditions: denaturation at $94^{\circ} \mathrm{C}$ for 1 min, annealing at $60^{\circ} \mathrm{C}$, and extension at $72^{\circ} \mathrm{C}$ for $1 \mathrm{~min}$ and $30 \mathrm{sec}$ (repeated for a total of 40 cycles). The first round PCR product was purified and then used as a template for second round PCR amplification (28 cycles) using the same primers in the first round. After PCR amplification, $8.5 \mu \mathrm{l}$ aliquot of reaction product was analyzed by electrophoresis on ethidium bromide-stained agarose gel $(1.5 \%)$. The primers used for AMPA receptor subunit cDNA amplification have been published previously (Lambolez et al., 1992). The primers for the detection of AMPA receptor subunit (GluR1-GluR4) cDNA were 5'-CCTTTGGCCTATGAGATCTGGATGTG-3' and 5'-TCGTACCACCATTTGTTTTTCA-3'. This set of primers is common to GluR1-GluR4 mRNA and coamplified all four AMPA receptor subunits (Lambolez et al., 1992). The size of amplified products is 749 bp for GluR1, GluR2, and GluR4, and 755 bp for GluR3, and they appear as a single band on electrophoresis gel. To determine the presence of specific GluR1-GluR4 mRNA, the amplified PCR products were cut with subunit-specific restriction enzymes. Aliquots $(10 \mu \mathrm{l})$ of the PCR product were digested with $\mathrm{Bg} / \mathrm{I}$ (for GluR1), Bsp1286I (for GluR2), Eco47III (for GluR3), and EcoRI (for GluR4) at $37^{\circ} \mathrm{C}$ for $2 \mathrm{hr}$. The enzyme-cleaved products were then analyzed with agarose gel electrophoresis and stained with ethidium bromide. The predicted restriction fragments were 300 and 449 bp for GluR1, 478 and $271 \mathrm{bp}$ for GluR2, 359 and $396 \mathrm{bp}$ for GluR3, and 411 and 338 bp for GluR4.

RT-PCR analysis of GluR5-GluR7 subunit mRNA used subunitspecific primer sets. Two rounds of amplification ( 45 cycles total) were performed using conditions similar to those described above (annealing temperature of $61^{\circ} \mathrm{C}$ ). Primer sets were derived from GenBank sequence using commercial primer design software (Oligo; National Biosciences, Plymouth, MN). The primers for detection of GluR5 cDNA (GenBank accession number M83560) (Bettler et al., 1990) were 5'-GCCCCTCTCACCATCACATAC-3' and 5'-ACCTCGCAATCACAAACAGTACA$3^{\prime}$. The predicted product length was $208 \mathrm{bp}$. The primer for detection of GluR6 cDNA (GenBank accession number Z11548) were 5'-TTCCTGAATCCTCTCTCCCCT- $3^{\prime}$ and $5^{\prime}$-CACCAAATGCCTCCCACTATC-3'. The predicted product length was $260 \mathrm{bp}$. The primers for detection of GluR 7 cDNA (GenBank accession number M83552) (Bettler et al., 1992) were 5'-TGGGCCTTCACCTTGATCATCA-3' and 5'ACTCCACACCCCGACCTTCT- $3^{\prime}$. The predicted product length was $423 \mathrm{bp}$. The primers for detection of KA-1-KA-2 cDNA (GenBank accession number 59996) were 5'-TGGGCCTTCACCTTGATCATCA-3' and 5'-CTGTGGTCCTCCTCCTTGGG-3'. The predicted product length was 512 bp.

Care was taken to ensure that PCR signal arose from cellular mRNA. Negative controls for contamination from extraneous and genomic DNA were run. To ensure that genomic DNA did not contribute to the PCR products, the cells were processed in the normal manner except that the reverse transcriptase was omitted. Contamination from extraneous sources was checked by replacing the cellular template with water. Both controls were consistently negative in these experiments.

Assay of $T N F-\alpha$. The isolated microglial cells were seeded in a 24-well plate at a density of $5.6 \times 10^{7}$ cells per well and were cultured for $3 \mathrm{~d}$. Then, the cells were treated with $10^{-3}$ M KA, Glu, NMDA, and AMPA. Most of the identified microglial cells displayed round or spindle shape. After treatment for $2 \mathrm{hr}$, the amount of rat TNF- $\alpha$ released into the culture medium was measured by an ELISA kit (Biosource, Camarillo, CA) having a detection limit of $2.3 \mathrm{pg} / \mathrm{ml}$ following the protocol provided by the manufacturer. The absorbency at $450 \mathrm{~nm}$ was performed by a Microplate Reader (model 450; Bio-Rad). The data are presented as 

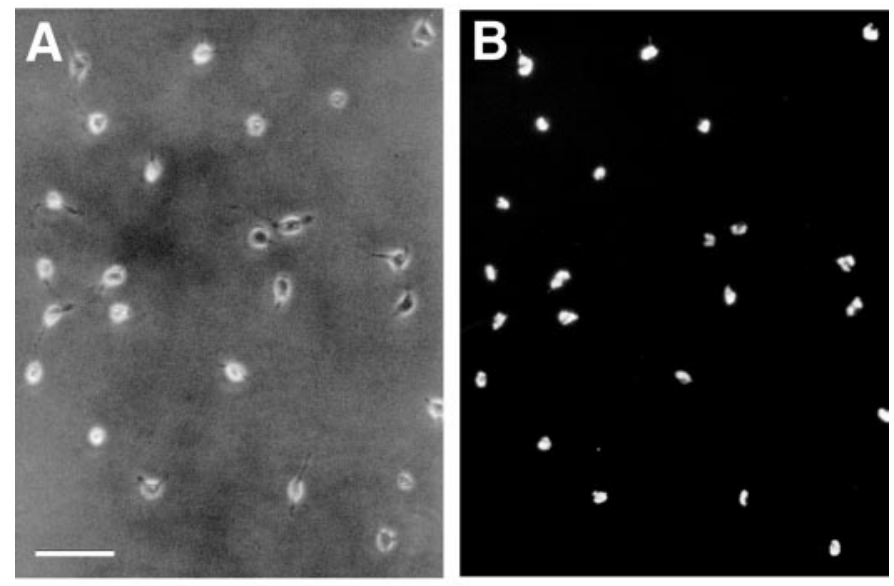

Figure 1. Identification of microglial cells using fluorescent probe DiIac-LDL. Microglial cells were visualized under the fluorescent microscope combined with phase-contrast modes $(A)$ and the fluorescent modes $(B)$ that were used for whole-cell patch-clamp recordings. Scale bar, $50 \mu \mathrm{m}$.

mean $\pm \mathrm{SD}$ of four to six experiments. The significance of differences between groups was determined with a two-way ANOVA, followed by Scheffé's post hoc test for multiple comparison when $F$ ratios reached significance.

\section{RESULTS}

\section{Identification of microglial cells}

Isolated microglial cells showed phase-bright small round- or rod-shaped cell bodies with no or few thick processes under the phase-contrast microscope (Fig. 1A). In some experiments, the identity of isolated cells used for electrophysiological measurements were confirmed by using DiI-ac-LDL, a fluorescent probe for scavenger receptors. As shown in Figure $1 B$, microglia identified by staining with DiI-ac-LDL (23 of 25 cells in this microscopic field) were clearly visualized under the inverted fluorescent microscope.

\section{Electrophysiological measurement of kainate-induced response}

Twenty percent (27 of 137) of the whole-cell patched microglial cells showed a response to $3 \times 10^{-4}$ to $10^{-3} \mathrm{M} \mathrm{KA}$. Application of KA induced an inward current under voltage-clamp conditions at the holding potential of $-60 \mathrm{mV}$ (Fig. $2 A$ ). The amplitude of $3 \times 10^{-4} \mathrm{M} \mathrm{KA}$-induced inward current was $28 \pm 5 \mathrm{pA}(n=17)$. However, in the same cell that responded to KA, application of AMPA between $10^{-4}$ and $10^{-3} \mathrm{M}$ induced apparently no or little inward current (Fig. 2Aa). Because AMPA responses showed very fast activation and inactivation (Partin et al., 1993; Patneau et al., 1994; Akaike and Rhee, 1997), we might not be able to measure such a transient current, even with our fast perfusion system at the temperature of $33-34^{\circ} \mathrm{C}$. The response to $\mathrm{KA}$ was reversibly cross-inhibited by addition of AMPA (Fig. $2 A a$ ), thus suggesting that KA and AMPA activated the same Glu receptor channel as found in the basket cells of rat hippocampal dentate gyrus (Koh et al., 1995) and Meynert neurons of rat nucleus basalis (Akaike and Rhee, 1997). Figure $2 A b$ shows the responses to other agonists for Glu receptor channels in a KA-responsive cell. Similar to AMPA responses, $3 \times 10^{-4} \mathrm{M}$ Glu or $3 \times 10^{-4} \mathrm{M}$
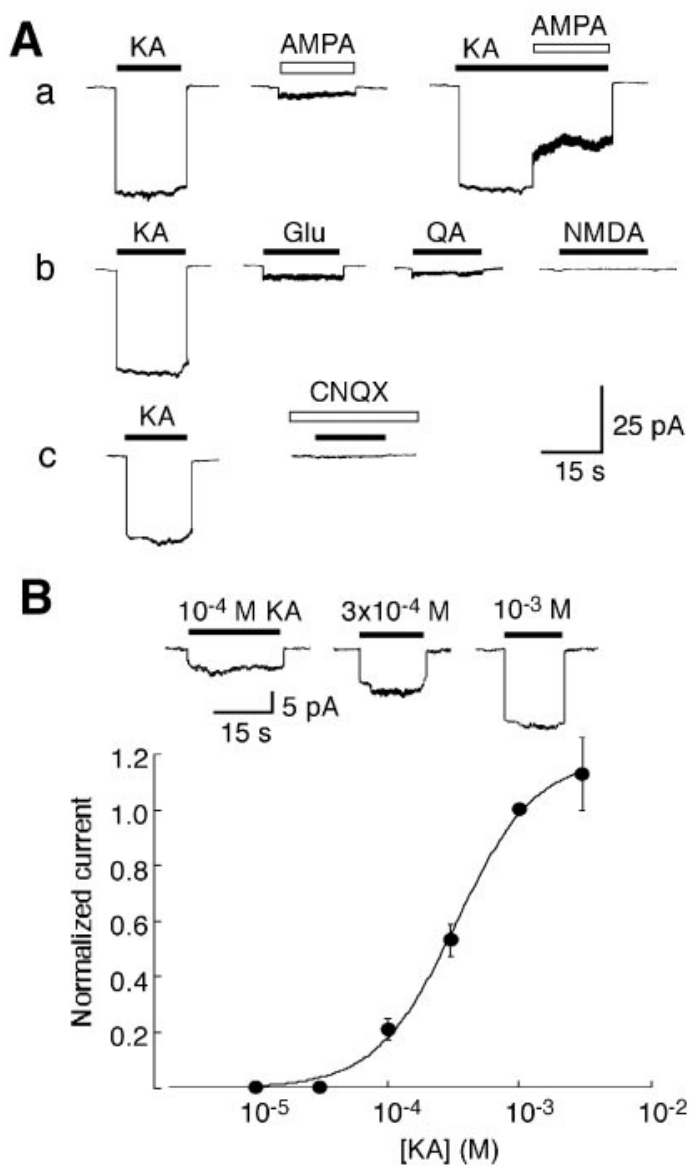

Figure 2. A, KA-induced current in rat microglia. $a$, KA $\left(3 \times 10^{-4} \mathrm{M}\right)$ induced an inward current, but apparently $3 \times 10^{-4}$ M AMPA induced very small inward current. There was cross-inhibition between KA and AMPA responses. $b$, In the same microglial cell, $3 \times 10^{-4}$ M KA but not $3 \times 10^{-4} \mathrm{M}$ NMDA (with $3 \times 10^{-6} \mathrm{M}$ glycine) induced an inward current. Glu $\left(3 \times 10^{-4} \mathrm{M}\right)$ and $3 \times 10^{-4} \mathrm{M}$ QA induced a small inward current. $c$, KA-induced $\left(3 \times 10^{-4} \mathrm{M}\right)$ current was blocked by $10^{-5} \mathrm{M}$ CNQX. The holding potential was $-60 \mathrm{mV}$. There are five other cells with similar results in $a-c$ each. $B$, Concentration-dependent effect of KA. The holding potential was $-40 \mathrm{mV}$. All currents were normalized to the response induced by $10^{-3} \mathrm{M}$ KA. Each point represents the mean of three cells. The curve shows the least-squares fit to the equation $a=b^{\mathrm{n}} /\left(b^{\mathrm{n}}+K^{\mathrm{n}}\right)$, where $a$ is relative activation, $b$ is agonist concentration (M), $n$ is Hill coefficient (1.4), and $K$ is the half-activation concentration $(0.33 \times$ $\left.10^{-3} \mathrm{M}\right)$.

QA induced a little current. There was no response to $3 \times 10^{-4}$ $\mathrm{M}$ NMDA in the presence of $3 \times 10^{-6} \mathrm{M}$ glycine and without extracellular $\mathrm{Mg}^{2+}$, suggesting microglia, unlike O-2A progenitor cells, have no NMDA receptor channel complexes (Wang et al., 1996). The response to $3 \times 10^{-4} \mathrm{M} \mathrm{KA}$ was totally suppressed in the presence of $10^{-5} \mathrm{M}$ CNQX (Fig. $2 A c$ ).

The KA-induced inward currents were concentrationdependent (Fig. $2 B$ ). Below $3 \times 10^{-5} \mathrm{M}$, KA did not induce any apparent inward current. In the KA-responsive cells, the amplitudes of inward current induced by each concentration of KA between $10^{-5}$ and $3 \times 10^{-3} \mathrm{M}$ were normalized to the one induced by $10^{-3} \mathrm{M} \mathrm{KA}$ in the same cell. The concentrationresponse relationship showed that the normalized maximum current amplitudes, half-activation concentration, and Hill coefficient were $1.19 \pm 0.05,0.33 \times 10^{-3} \mathrm{M}$, and $1.4 \pm 0.2(n=3)$, respectively. 


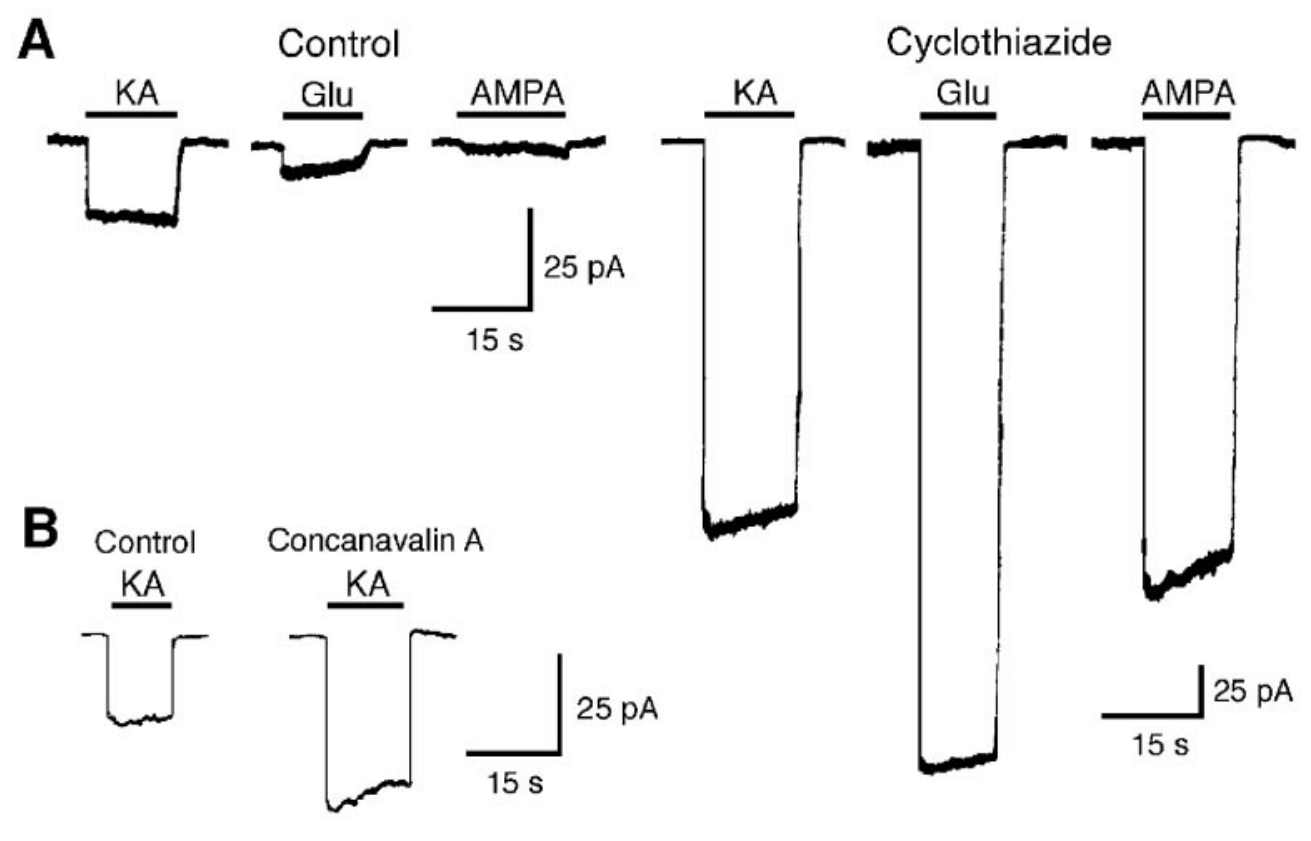

Figure 3. Cyclothiazide strongly potentiated KA-, Glu-, and AMPAinduced inward currents, but concanavalin A did not always potentiate KAinduced current. $A$, Inward current evoked by $3 \times 10^{-4} \mathrm{M} \mathrm{KA}$, Glu, and AMPA before (left) and during application of $10^{-4} \mathrm{M}$ cyclothiazide $(>3 \mathrm{~min})$ (right) in the same cell. $B$, In some cells, inward current evoked by $3 \times 10^{-4} \mathrm{M}$ KA was potentiated by adding 0.3 $\mathrm{mg} / \mathrm{ml}$ concanavalin A (>3 min).
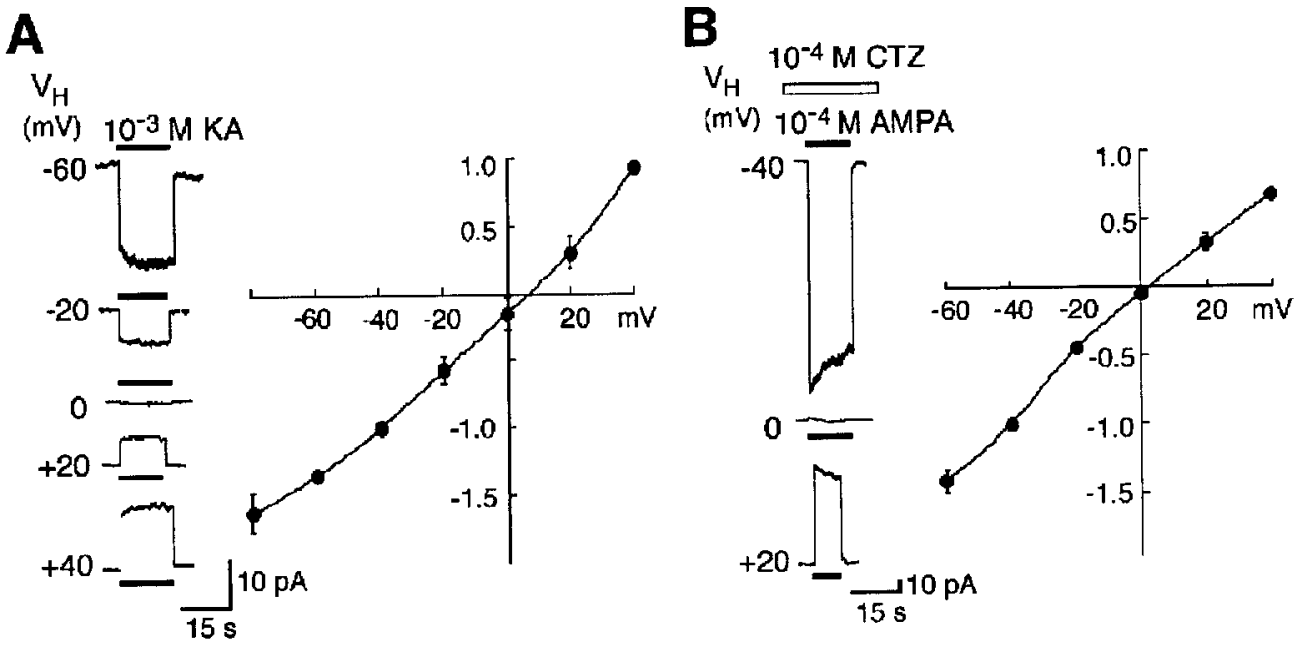

Figure 4. Current-voltage relationships of KA- and AMPA-induced currents. $A, \mathrm{KA}$-induced $\left(10^{-3} \mathrm{M}\right)$ currents at different holding potentials and the $I-V$ relationships. $B$, AMPA-induced $\left(10^{-4} \mathrm{M}\right)$ currents in the presence of $10^{-4}$ M CTZ. All current amplitudes were normalized to the peak current at a holding potential of $-40 \mathrm{mV}$. Each point represents the mean of three to four cells. Some error bars are within the circles.

\section{Effects of cyclothiazide and concanavalin A on KA, Glu, and AMPA responses}

CTZ blocks desensitization of AMPA-preferring receptors and produces marked potentiation of the response to KA or Glu (Patneau et al., 1993; Trussell et al., 1993; Yamada and Tang, 1993; Akaike and Rhee, 1997). Studies using KA-preferring receptors and recombinant AMPA- and KA-preferring receptors show that the action of $\mathrm{CTZ}$ is selective for AMPA-preferring receptors (subunits GluR1-GluR4) and that concanavalin A is selective for KA-preferring receptors (subunits GluR5-GluR7 and KA-1 or KA-2) (Huettner, 1990; Partin et al., 1993; Wong and Mayer, 1993).

In KA-responsive microglial cells, CTZ greatly potentiated KA-, Glu-, and AMPA-induced inward currents (Fig. $3 A$ ) in all five cells tested. Furthermore, the relatively small response to Glu and AMPA became greater than the response to KA in the presence of CTZ. After application of CTZ, the desensitization after the peak Glu- and AMPA-induced current diminished in a time-dependent manner, finally showing the steady-state current like KA-induced current ( $\sim 20 \mathrm{~min}$; data not shown). These results suggest that KA-responsive cells all express AMPApreferring receptors. On the other hand, in only two of seven KA-responsive cells, KA-induced current was affected by application of concanavalin A $(0.3 \mathrm{mg} / \mathrm{ml} ;>3 \mathrm{~min})$ (Fig. $3 B)$. This result suggests that only some of the KA-responsive cells express KA-preferring receptors and not only AMPA-preferring receptors. When we treated cells with concanavalin A before determining whether they respond to KA, the KA-responsive cells were 4 of 10 cells (data not shown). These results also indicate the heterogeneous distribution of AMPA- and KA-preferring receptors among microglial cells; some cells express predominantly AMPA-preferring receptors, some cells express predominantly KA-preferring receptors, and some cells express both.

Figure 4 shows the $I-V$ relationships of the responses to $10^{-3} \mathrm{M}$ $\mathrm{KA}$ and $10^{-4} \mathrm{M}$ AMPA. The $I-V$ relationships (normalized to the respective peak current amplitudes at $-40 \mathrm{mV}$ ) reversed at $\sim 0$ to $-10 \mathrm{mV}$. The rather linear shape of the $I-V$ relationship of the $\mathrm{KA}$ response in $\mathrm{Na}^{+}$-containing solution pointed to the possible expression of glial AMPA receptor with low $\mathrm{Ca}^{2+}$ permeability (Hollmann et al., 1991; Burnashev et al., 1992). 


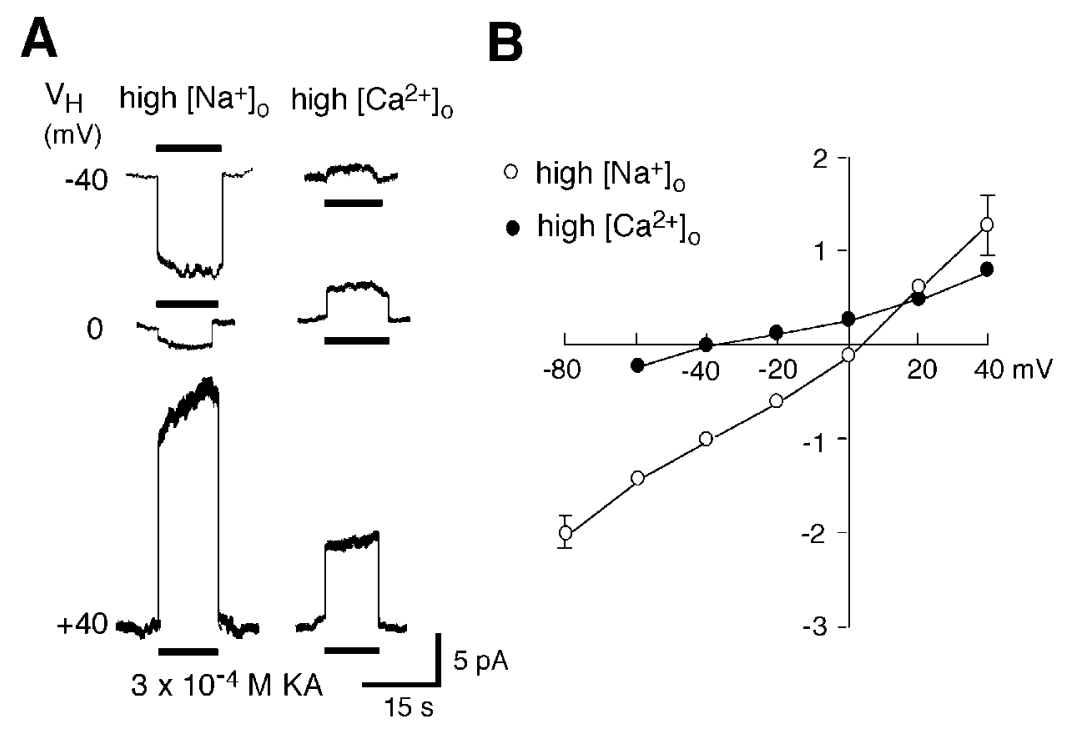

Figure 5. KA-induced currents in high $\mathrm{Na}^{+}$and high $\mathrm{Ca}^{2+}$ external solutions. $A$, KA-induced $\left(10^{-3} \mathrm{M}\right)$ currents at different holding potentials in high $\mathrm{Na}^{+}$and high $\mathrm{Ca}^{2+}$ external solutions. B, $I-V$ relationships in high $\mathrm{Na}^{+}$and high $\mathrm{Ca}^{2+}$ external solutions. All current amplitudes were normalized to the peak current at a holding potential of $-40 \mathrm{mV}$. Each point represents the mean of three to four cells. Some error bars are within the circles.
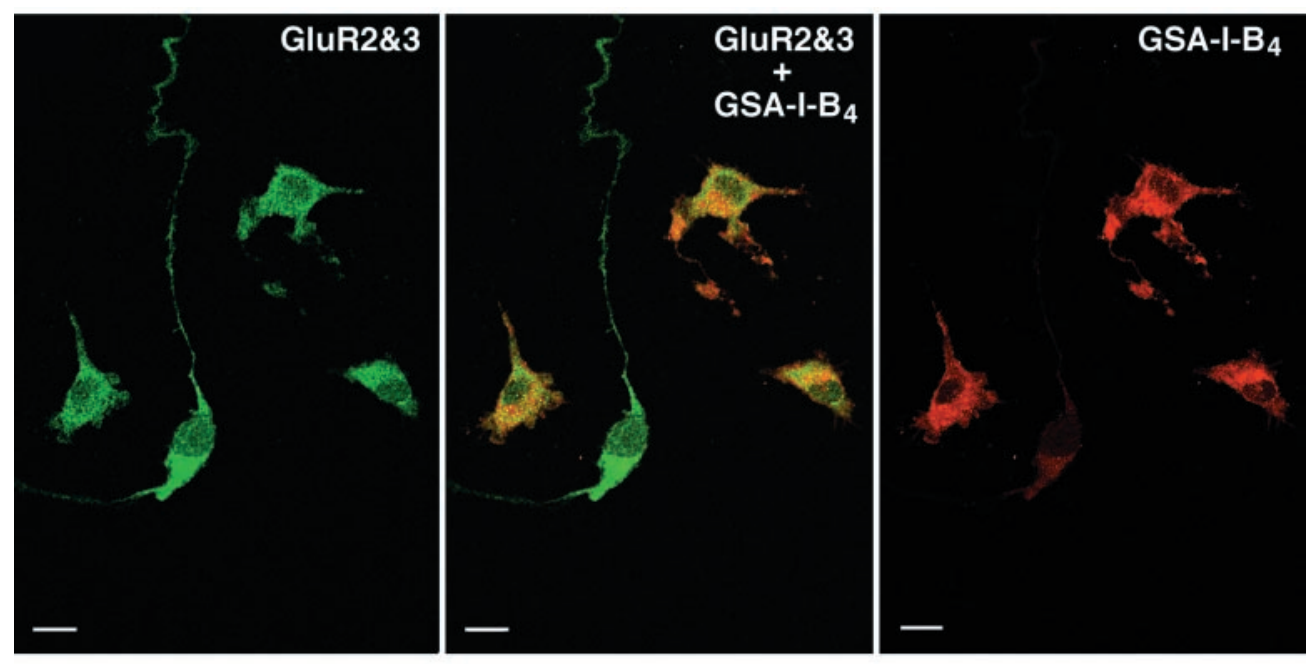

Figure 6. Localization of AMPApreferring subunits of Glu receptor on microglia. Staining with anti-Glu receptor 2 and 3 antibody (green) and with GSA-I-B ${ }_{4}($ red $)$ were visualized by confocal laser scanning microscope images. Scale bars, $10 \mu \mathrm{m}$.

To estimate the divalent permeability of the receptor channel complexes activated by KA, the external solutions were switched from high $\mathrm{Na}^{+}\left(110\left[\mathrm{Na}^{+}\right] / 3\left[\mathrm{Ca}^{2+}\right]\right)$ to high $\mathrm{Ca}^{2+}\left(80\left[\mathrm{Ca}^{2+}\right] / 0\right.$ $\left[\mathrm{Na}^{+}\right]$) concentrations (Fig. 5). Under these conditions, KAinduced inward current at -40 and $0 \mathrm{mV}$ turned to outward current (Fig. 5A), and the mean reversal potential shifted to negative potential of approximately $-40 \mathrm{mV}(n=3)$ (Fig. $5 B)$. Nevertheless, the activation of receptor currents in external solutions with $\mathrm{Ca}^{2+}$ being the charge carrier for the GluR channel, together with a rather positive deviation of the reversal potential from that expected for channels with an exclusive monovalent permeability (far negative because no monovalent cation was included in high $\mathrm{Ca}^{2+}$ solution), indicated an intermediate $\mathrm{Ca}^{2+}$ permeability of this GluR channel (Seifert and Steinhäuser, 1995; Washburn et al., 1997). To estimate the relative permeability of the GluR channels to $\mathrm{Ca}^{2+}$, the following constant field equation was used:

$$
P_{\mathrm{Ca}} / P_{\mathrm{Na}}=\left(\left[\mathrm{Na}^{+}\right]_{\mathrm{i}} /\left[\mathrm{Ca}^{2+}\right]_{\mathrm{o}}\right)(\exp (V F / R T)[\exp (V F / R T)+1] / 4)
$$

where $V$ is the reversal potential, $F, R$, and $T$ have their usual meanings, $\left[\mathrm{Ca}^{2+}\right]_{\mathrm{o}}$ is the extracellular $\mathrm{Ca}^{2+}$ concentration, and
$P_{\mathrm{Ca}}$ and $P_{\mathrm{Na}}$ represent the permeability coefficient of $\mathrm{Ca}^{2+}$ and $\mathrm{Na}^{+}$, respectively (Iino et al., 1990). Then, we obtained a permeability ratio of $P_{\mathrm{Ca}} / P_{\mathrm{Na}}=0.26$.

\section{Immunocytochemical study of AMPA receptor}

The low $\mathrm{Ca}^{2+}$ permeability of AMPA receptors in microglial cells suggests that they include GluR2 (Hollmann et al., 1991; Hume et al., 1991; Verdoorn et al., 1991; Burnashev et al., 1992). Therefore, the existence of AMPA receptors on microglia was examined by a double-staining technique using anti-GluR2 and 3 antibody (Alexia 488 labeling; green) and GSA-I-B 4 (Cy3 labeling; red) (Fig. 6). Spindle-shaped cells were moderately stained by anti-GluR2 and 3 and identified to be microglia by GSA-I-B 4 staining. A small population of cells (5-8\%), which had fusiform cell bodies with long processes and assumed to be O-2A cells, were intensely stained by anti-GluR 2 and 3 antibody but devoid of GSA-I-B ${ }_{4}$ staining. This staining pattern clearly demonstrated that microglia possessed moderate amount of GluR2 and/or GluR3. No immunoreaction was detected in control experiments with nonimmune IgG. 

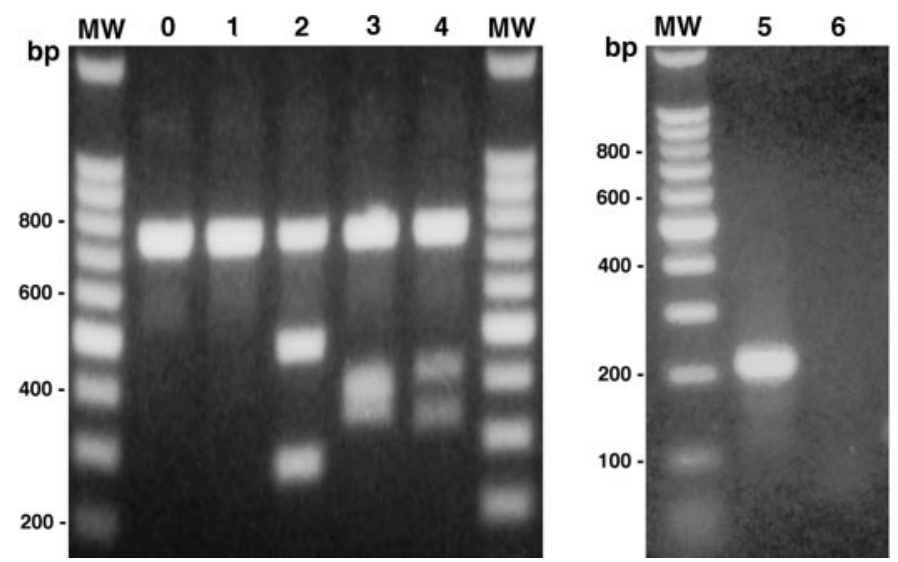

Figure 7. RT-PCR was performed on mRNA harvested from rat microglia to determine the subunits of AMPA-KA receptor mRNA. The AMPA subunit content was determined by a two-step procedure. First, cDNA for GuR1-GluR4 subunits were PCR-amplified simultaneously using primers common to all four subunits. Separate fractions of these PCR products were then treated with subunit-specific restriction enzyme for GluR1 (lane 1), GluR2 (lane 2), GluR 3 (lane 3), GluR4 (lane 4), or without treatment (lane 0 ). The PCR products and/or restriction enzyme products were visualized using gel electrophoresis and ethidium bromide staining and were identified by their size. It shows that rat microglia contain GluR2-GluR4, whereas GluR1 is barely detectable. For PCR analysis of KA receptor mRNAs, the subunit-specific primer sets were used. The PCR products showed detectable GluR5 (lane 5) but not GluR6 (lane 6).

\section{Identification of AMPA-KA receptor subunits by RT-PCR}

Our RT-PCR study of AMPA receptor subunits showed that rat microglia contained GluR2, GluR3, and GluR4 mRNAs (Fig. 7). The amplified PCR products, which contained all GluR1-GluR4 and appeared as a single band on electrophoresis gels, were cut with subunit-specific restriction enzymes, except for GluR1 (Fig. 7, lane 1). The predicted restriction fragments were found for GluR2 (Fig. 7, lane 2), GluR3 (Fig. 7, lane 3), and GluR4 (Fig. 7, lane 4), respectively.

Our RT-PCR studies of KA receptor subunits are more preliminary. GluR5 mRNA was detected (Fig. 7, lane 5), but GluR6 mRNA was not expressed at detectable levels (Fig. 7, lane 6). GluR7 and KA-1-KA-2 mRNAs were detected in a subpopula- tion of these cells, indicative of lower mRNA abundance (data not shown).

\section{Enhanced production of TNF- $\alpha$ from microglia by treatment with KA}

To elucidate whether AMPA-KA receptors on microglia have functional consequences because microglia are known to produce cytokines after cellular activation (McGeer et al., 1993; Meda et al., 1995), the release of TNF- $\alpha$ before and after treatment of KA and other Glu agonists was measured. As shown in Figure 8, microglia constitutively produced small amounts of TNF- $\alpha$. When microglia were treated with $10^{-3} \mathrm{M} \mathrm{KA}$, the amount of TNF- $\alpha$ released in the culture medium at $2 \mathrm{hr}$ after the treatment was significantly increased (Fig. $8 A$ ). Similar enhancement was also observed after the treatment with $10^{-3} \mathrm{M}$ Glu. On the other hand, neither NMDA nor AMPA had any significant effect on the production of TNF- $\alpha$ by microglia. Both Glu- and KA-induced productions of TNF- $\alpha$ were significantly depressed by adding $2 \times$ $10^{-5}$ м CNQX (Fig. $8 B$ ).

\section{DISCUSSION}

The present studies provide the first evidence for the existence of AMPA-KA subunits of Glu receptor in primary cultured rat microglia. Although the present immunohistochemical and RTPCR analyses clearly showed that microglia have a substantial amount of GluR2-GluR5, the net inward current induced by either Glu or AMPA was very small compared with that induced by $\mathrm{KA}$ at the holding potential of -40 or $-60 \mathrm{mV}$. One possible explanation for this apparent discrepancy is that AMPA- and Glu-activated currents are desensitized very fast and the fast response could not be detected, even with our fast perfusion system using the $\mathrm{Y}$ tube technique. To test this possibility, we examined the effects of CTZ and concanavalin A, agents that block the desensitization of AMPA- and KA-preferring receptors, respectively. We found that CTZ markedly enhanced KA-, AMPA-, and Glu-activated currents in all of the KA-responsive microglia. Concanavalin A not only augmented the amplitude of KA-induced current in some of the KA-responsive microglia but also seemed to unmask KA receptors, which were supposedly expressed predominantly in some cells and were missed without concanavalin A. Thus, the extremely fast desensitization or very small response of AMPA- and KA-preferring receptors (Partin et al., 1993; Swanson and Heinemann, 1998) is likely to be mainly
Figure 8. Effects of KA on the production of TNF- $\alpha$ by microglia. The amount of TNF- $\alpha$ released in the culture medium of microglia at $2 \mathrm{hr}$ after stimulation was measured by ELISA. $A$, Effects of $10^{-3} \mathrm{M}$ Glu, NMDA, KA, and AMPA on the production of TNF- $\alpha$ by microglia. ${ }^{* *} p<0.01,{ }^{* * *} p<0.001$, compared with control (two-way ANOVA). $B$, Effects of CNQX $\left(2 \times 10^{-5} \mathrm{M}\right)$ on the $10^{-3} \mathrm{M}$ Glu-induced and $10^{-3}$ M KA-induced TNF- $\alpha$ production. ${ }^{* *} p<0.05$, ${ }^{* * *} p<0.001$, compared with control; ${ }^{\dagger} p<0.05,{ }^{\dagger} p<$ 0.01 , compared with the data obtained in the absence of CNQX (two-way ANOVA).
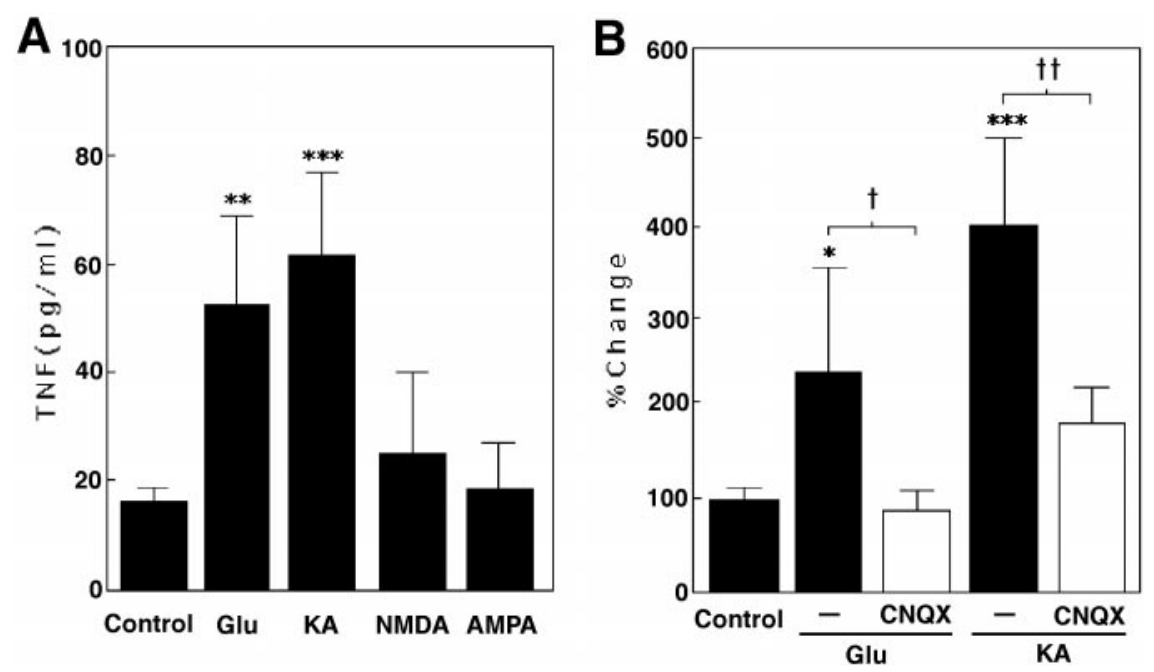
responsible for the fact that their existence in microglia has long gone unnoticed. According to Raman and Trussell (1992), glutamate-evoked currents in neurons of the chicken cochlea nucleus desensitizes very rapidly, and the high temperature accelerates desensitization. However, it is not unreasonable to speculate that the transient and localized activation of an ionotropic receptor could be greatly amplified when assaying its downstream effects, because many receptors can be tightly linked to other proteins that may be involved in initiation of intracellular cascade. In addition, we also speculate that there might exist an endogenous active factor that can augment the response of AMPA- and KA-preferring receptors in microglia, such as glycine for NMDA receptors as reported by Johnson and Ascher (1987). Alternatively, pathological states, for example extracellular acidity as suggested by McDonald et al. (1998), may potentiate AMPA and KA receptor-mediated responses. Further investigations are necessary to clarify this point.

Although the subtype composition of Glu receptor expressed in rat microglia was not yet known, we hypothesized that at least GluR2 should be expressed, because either KA- or AMPAactivated receptor channels have poor $\mathrm{Ca}^{2+}$ permeability (Fig. $5)$. This expectation was preliminarily confirmed from doublelabeling immunohistochemical studies using anti-GluR2 and 3 antibody (Fig. 6). Then, the precise expression of AMPA receptor subunits in microglia was analyzed by RT-PCR, which showed that rat microglia contained GluR2-GluR4 (Fig. 7). Because it was clear that KA receptors were also present in some cells from the electrophysiological data using concanavalin A, we further analyzed the expression of mRNAs for KA receptor subunits. The results clearly showed the expression of mRNA for GluR5 (Fig. 7) and indicated the lower expression levels of mRNAs for GluR7 and KA-1-KA-2. On the other hand, O-2A lineage cells express mRNAs for GluR2-GluR4, in addition to GluR6, GluR7, KA-1, and KA-2 (Patneau et al., 1994). Our microglial cells, especially for RT-PCR, were carefully isolated without any contamination of other cells, i.e., O-2A cells, so that we could exclude the possibility that mRNA for GluR from other cell types were amplified.

The physiological role of these AMPA-KA receptors in rat microglia also remains unclear. However, we found that Glu and KA can enhance production of TNF- $\alpha$ (Fig. 8). It is possible that elevated levels of Glu in pathological sites may directly activate AMPA-KA receptors on microglia contributing enhanced production of TNF- $\alpha$. Recently, expression and signaling of metabotropic glutamate receptor in microglia has been reported (Biber et al., 1999), which might also contribute to the functional role of Glu in microglia. The mechanism and the signal transduction pathways mediating from GluR to TNF- $\alpha$ production in microglia are not known. However, it may be common to those used by these cells in response to inflammatory stimuli, i.e., tyrosine kinase-based signaling cascade (Combs et al., 1999). Because the cascade reported so far contains $\mathrm{Ca}^{2+}$-sensitive pathway, TNF- $\alpha$ production by Glu and KA is also suggested to be dependent on intracellular $\mathrm{Ca}^{2+}$, indicating that low $\mathrm{Ca}^{2+}$ permeability of KA-mediated response might have been enough for it. It might also be possible that KA receptors rather than AMPA receptors are more likely mediators of the increase in TNF- $\alpha$ production because of the lack of effect of AMPA on TNF- $\alpha$. Whether or not AMPA receptors and $\mathrm{KA}$ receptors exhibit different $\mathrm{Ca}^{2+}$ permeability, which receptors are dominating the responses we observed and their signaling cascade are now under investigation. As for the function of TNF- $\alpha$, although TNF- $\alpha$ production rapidly increases after excitotoxic, ischemic, and traumatic brain injuries (Minami et al., 1991; Taupin et al., 1993; Liu et al., 1994), the effects of TNF- $\alpha$ on neurons remains controversial. For example, Chao and $\mathrm{Hu}$ (1994) have reported that TNF- $\alpha$ potentiates Glu neurotoxicity, whereas Cheng et al. (1994) have shown that TNF- $\alpha$ protects neurons against excitotoxic insults. On the other hand, TNF- $\alpha$, as well as other cytokines, are also known to work on glial cells and to kill oligodendrocytes (Selmaj and Raine, 1988; Louis et al., 1993), leading to destruction of myelin and the dysfunction of axons (Merrill and Benveniste, 1996). Based on these assumptions, more precise analysis of the functions and the characteristics of Glu receptors in microglia will contribute to a better understanding of the physiological and pathological events in the CNS.

\section{REFERENCES}

Akaike N, Rhee JS (1997) Age-related functional changes of the glutamate receptor channels in rat Meynert neurones. J Physiol (Lond) 504:665-681.

Araujo DM, Cotman CW (1992) Basic FGF in astroglial, microglial, and neuronal cultures: characterization of binding sites and modulation of release by lymphokines and trophic factors. J Neurosci 12:1668-1678.

Bettler B, Boulter J, Hermans-Borgmeyer I, O'Shea-Greenfield A, Deneris ES, Moll C, Borgmeyer U, Heinemann S (1990) Cloning of a novel glutamate receptor subunit, GluR5: expression in the nervous system during development. Neuron 5:583-595.

Bettler B, Egebjerg J, Sharma G, Pecht G, Hermans-Borgmeyer I, Moll C, Stevens CF, Heinemann S (1992) Cloning of a putative glutamate receptor: a low affinity kainate-binding subunit. Neuron 8:257-265.

Bezzi P, Carmignoto G, Pasti L, Vesce S, Rossi D, Rizzini BL, Pozzan T, Volterra A (1998) Prostaglandins stimulate calcium-dependent glutamate release in astrocytes. Nature 391:281-285.

Biber K, Laurie DJ, Berthele A, Sommer B, Tölle TR, Gebicke-Härter PJ, Van Calker D, Boddeke HWGM (1999) Expression and signaling of group I metabotropic glutamate receptors in astrocytes and microglia. J Neurochem 72:1671-1680.

Bowman CL, Kimelberg HK (1984) Excitatory amino acids directly depolarize rat brain astrocytes in primary culture. Nature 311:656-659.

Burnashev N, Monyer PH, Seeburg B, Sackmann B (1992) Divalent ion permeability of AMPA receptor channels is dominated by edited of a single subunit. Neuron 8:189-198.

Chao CC, Hu S (1994) Tumor necrosis factor-alpha potentiates glutamate neurotoxicity in human fetal brain cell cultures. Dev Neurosci 16:172-179.

Cheng B, Christakos S, Mattson MP (1994) Tumor necrosis factors protect neurons against excitotoxic/metabolic insults and promote maintenance of calcium homeostasis. Neuron 12:139-153.

Chessell IP, Michel AD, Humphrey PPA (1997) Properties of the poreforming $\mathrm{P}_{2} \mathrm{X}_{7}$ purinoceptor in mouse NTW8 microglial cells. $\mathrm{Br} \mathrm{J}$ Pharmacol 121:1429-1437.

Combs CK, Johnson DE, Cannady SB, Lehman TM, Landreth GE (1999) Identification of microglial signal transduction pathways mediating a neurotoxic response to amyloidogenic fragments of $\beta$-amyloid and prion proteins. J Neurosci 19:928-939.

Cornell-Bell AH, Finkbeiner SM, Cooper MS, Smith SJ (1990) Glutamate induces calcium waves in cultured astrocytes: long range glial signalling. Science 247:470-474.

El Khoury J, Hickman SE, Thomas CA, Cao L, Silverstein SC, Loike JD (1996) Scavenger receptor mediated adhesion of microglia to $\beta$-amyloid fibrils. Nature 382:716-719.

Gallo V, Giovannini C, Suergiu R, Levi G (1989) Expression of excitatory amino acid receptors by cerebellar cells of the type-2 astrocyte lineage. J Neurochem 52:1-9.

Hollmann M, Hartley S, Heinemann S (1991) $\mathrm{Ca}^{2+}$ permeability of KA-AMPA-gated glutamate receptor channels depends on subunit composition. Science 252:851-853.

Huettner JE (1990) Glutamate receptor channels in rat DRG neurons: activation by kainate and quisqualate, and blockade of desensitization by Con A. Neuron 5:255-266.

Hume RI, Dingledine DR, Heinemann SF (1991) Identification of a site in glutamate receptor subunits that controls calcium permeability. Science 253:1028-1031. 
Iino M, Ozawa S, Tsuzuki K (1990) Permeation of calcium through excitatory amino acid receptor channels in cultured rat hippocampal neurons. J Physiol (Lond) 424:151-165.

Inoue K, Nakajima K, Morimoto T, Kikuchi Y, Koizumi S, Illes P, Kohsaka S (1998) ATP stimulation of $\mathrm{Ca}^{2+}$-dependent plasminogen release from cultured microglia. Br J Pharmacol 123:1304-1310.

Johnson JW, Ascher P (1987) Glycine potentiates the NMDA response in cultured mouse brain neurons. Nature 325:529-531.

Koh DS, Geiger JR, Jonas P, Sakmann B (1995) $\mathrm{Ca}^{2+}$-permeable AMPA and NMDA receptor channels in basket cells of rat hippocampal dentate gyrus. J Physiol (Lond) 485:383-402.

Kreuzberg GW (1996) Microglia: a sensor for pathological events in the CNS. Trends Neurosci 19:312-318.

Lambolez B, Audinat E, Bochet P, Crepel F, Rossier J (1992) AMPA receptor subunits expressed by single Purkinje cells. Neuron 9:247-258.

Liu T, Clark RK, McDonnell PC, Young PR, White RF, Barone FC, Feuerstein GZ (1994) Tumor necrosis factor- $\alpha$ expression in ischemic neurons. Stroke 25:1481-1488.

Louis JC, Magal E, Takayama S, Varon S (1993) CNTF protection of oligodendrocytes against natural and tumor necrosis factor-induced death. Science 259:689-692.

Mallat M, Houlgatte R, Brachet P, Prochiantz A (1989) Lipopolysaccharide-stimulated rat brain macrophages release NGF in vitro. Dev Biol 133:309-311.

Matute C, Sánches-Gómez MV, Martínez-Millán L, Miledi R (1997) Glutamate receptor-mediated toxicity in optic nerve oligodendrocytes. Proc Natl Acad Sci USA 94:8830-8835.

McDonald JW, Bhattacharyya T, Sensi SL, Lobner D, Ying HS, Canzoniero LM, Choi DW (1998) Extracellular acidity potentiates AMPA receptor-mediated cortical neuronal death. J Neurosci 18:6290-6299.

McGeer PL, Kawamata T, Walker DG, Akiyama H, Tooyama I, McGeer EG (1993) Microglia in degenerative neurological disease. Glia 7:84-92.

Meda L, Cassarella MA, Szendrei GI, Otvos Jr L, Baron P, Villalba M, Ferrari D, Rossi F (1995) Activation of microglial cells by $\beta$-amyloid protein and interferon- $\gamma$. Nature 374:647-650.

Merrill JE, Benveniste EN (1996) Cytokines in inflammatory brain lesions: helpful and harmful. Trends Neurosci 19:331-338.

Min BI, Kim CJ, Rhee JS, Akaike N (1996) Modulation of glycininduced chloride current in acutely dissociated rat periaqueductal gray neurons by $\mu$-opioid agonist DAGO. Brain Res 734:72-78.

Minami M, Kuraishi Y, Satoh M (1991) Effects of kainic acid on messenger RNA levels of IL-1 beta, IL-6, TNF- $\alpha$ and LIF in the rat brain. Biochem Biophys Res Commun 176:593-598.

Möller T, Kann O, Prinz M, Kirchhoff F, Verkhratsky A, Kettenmann H (1997) Endothelin-induced calcium signaling in cultured mouse microglial cells is mediated through ETB receptors. NeuroReport $8: 2127-2131$

Müller T, Möller T, Berger T, Schnitzer J, Kettenmann H (1992) Calcium entry through kainate receptors and resulting potassium-channel blockade in Bergmann glial cells. Science 256:1563-1565.

Nakajima K, Tsuzaki N, Shimojo M, Hamanoue M, Kohsaka S (1992a) Microglia isolated from rat brain secrete a urokinase-type plasminogen activator. Brain Res 577:285-292.

Nakajima K, Tsuzaki N, Nagata K, Takemoto N, Kohsaka S (1992b) Production and secretion of plasminogen in cultured rat brain microglia. FEBS Lett 308:179-182.

Noda M, Obana M, Akaike N (1998) Inhibition of M-type $\mathrm{K}^{+}$current by linopirdine, a neurotransmitter release enhancer, in NG108-15 neuronal cells and rat cerebral neurons in culture. Brain Res 794:274-280.

Noda M, Nakanishi H, Akaike N (1999) Glutamate release from microglia via glutamate transporter is enhanced by amyloid- $\beta$ peptide. Neuroscience 92:1465-1474.

Parpura V, Basarsky TA, Liu F, Jeftinija K, Jeftinija S, Haydon PG (1994) Glutamate-mediated astrocyte-neuron signalling. Nature 369:744-747.

Partin KM, Patneau DK, Winters CA, Mayer ML, Buonanno A (1993) Selective modulation of desensitization at AMPA versus kainate receptors by cyclothiazide and concanavalin A. Neuron 11:1069-1082.

Patneau DK, Vyklicky Jr L, Mayer ML (1993) Hippocampal neurons exhibit cyclothiazide-sensitive rapidly desensitizing responses to kainate. J Neurosci 13:3496-3509.

Patneau DK, Wright PW, Winters C, Mayer ML, Gallo V (1994) Glial cells of the oligodendrocytes lineage express both kainate- and AMPApreferring subtypes of glutamate receptor. Neuron 12:357-371.

Queiroz G, Gebicke-Haerter PJ, Schobert A, Starke K, Von Kugelgen I (1997) Release of ATP from cultured rat astrocytes elicited by glutamate receptor activation. Neuroscience 78:1203-1208.

Raman IM, Trussell LO (1992) The kinetics of the response to glutamate and kainate in neurons of the avian cochlear nucleus. Neuron 9:173-186.

Sastradipula DF, Nakanishi H, Tsukuba T, Nishishita K, Sakai H, Kato Y, Gotow T, Uchiyama Y, Yamamoto K (1998) Identification of cellular compartments involved in processing of cathepsin $\mathrm{E}$ in primary cultures of rat microglia. J Neurochem 70:2045-2056.

Seifert G, Steinhäuser C (1995) Glial cells in the mouse hippocampus express AMPA receptors with an intermediate $\mathrm{Ca}^{2+}$ permeability. Eur J Neurosci 7:1872-1881.

Selmaj K, Raine CS (1988) Tumor necrosis factor mediates myelin and oligodendrocyte damage in vitro. Ann Neurol 21:339-346.

Shimojo M, Nakajima K, Takei N, Hamanoue M, Kohsaka S (1991) Production of basis fibroblast growth factor in cultured brain microglia. Neurosci Lett 155:11-14.

Sontheimer H, Kettenmann H, Backus KH, Schachner M (1988) Glutamate opens $\mathrm{Na}^{+} / \mathrm{K}^{+}$channels in cultured astrocytes. Glia 1:328-336.

Stefani A, Chen Q, F-Hernandez J, Jiao Y, Reiner A, Surmeier D J (1998) Physiological and molecular properties of AMPA/kainate receptors expressed by striatal medium spiny neurons. Dev Neurosci 20:242-252.

Steinhäuser C, Gallo V (1996) News on glutamate receptors in glial cells. Trends Neurosci 19:339-345.

Streit WJ, Kincaid-Colton CA (1995) The brain's immune system. Sci Am 273:38-43.

Swanson GT, Heinemann SF (1998) Heterogeneity of homomeric GluR5 kainate receptor desensitization expressed in HEK293 cells. J Physiol (Lond) 513:639-646.

Taupin V, Toulmond S, Serrano A, Benavides J, Zavala F (1993) Increase in IL-6, IL-1 and TNF levels in rat brain following traumatic lesion. Influence of pre- and post-traumatic treatment with Ro5 4864: a peripheral-type ( $\mathrm{p}$ site) benzodiazepine ligand. J Neuroimmunol 42:177-185.

Trussell LO, Zhang S, Raman I (1993) Desensitization of AMPA receptors upon multiquantal neurotransmitter release. Neuron 10:1185-1196.

Usowicz MM, Gallo V, Cull-Candy SG (1989) Multiple conductance channels in type-2 cerebellar astrocytes activated by excitatory amino acids. Nature 339:380-383.

Verdoorn TA, Burnashev H, Monyer PH, Seeburg B, Sackmann B (1991) Structural determinations of ion flow through recombinant glutamate receptor channels. Science 252:1715-1718.

Verkhratsky A, Kettenmann H (1996) Calcium signalling in glial cells. Trends Neurosci 19:346-352.

Wang C, Pralong W-F, Schulz M-F, Rougon G, Aubry J-M, Pagliusi S, Robert A, Kiss JZ (1996) Functional $N$-methyl-D-aspartate receptors in O-2A glial precursor cells: a critical role in regulating polysialic acid-neural cell adhesion molecule expression and cell migration. J Cell Biol 135:1565-1581.

Washburn MS, Numberger M, Zhang S, Dingledine R (1997) Differential dependence on GluR2 expression of three characteristic features of AMPA receptors. J Neurosci 17:9393-9406.

Wong L, Mayer ML (1993) Differential modulation by cyclothiazide and concanavalin A of desensitization at native $\alpha$-amino-3-hydroxy-5methyl-4-isoxazolepropionic acid and kainate-preferring glutamate receptors. Mol Pharmacol 44:504-510.

Wyss-Coray T, Masliah E, Mallory M, McConlogue L, Johnson-Wood K, Lin C, Mucke L (1997) Amyloidogenic role of cytokine TGF- $\beta 1$ in transgenic mice and in Alzheimer's disease. Nature 389:603-606.

Yamada KA, Tang C-M (1993) Benzothiadiazides inhibit rapid glutamate receptor desensitization and enhance glutamatergic synaptic currents. J Neurosci 13: 3904-3915. 